\title{
Biodiversity and distribution of groundwater fauna in the Oum-El-Bouaghi region (Northeast of Algeria)
}

\author{
KHAMMAR HICHEM ${ }^{\boldsymbol{\gamma}}$, HADJAB RAMZI, MERZOUG DJEMOI \\ Laboratory of Functional Ecology and Environment, Department of Life Sciences and Nature, Faculty of Exact Sciences and Life Sciences and Nature, \\ University of "Larbi Ben M'hidi", Oum El Bouaghi. 1st November 1954, Oum el Bouaghi 04000. Algeria. Tel: +213-661-221833. \\ "email: khammar.eco.env@gmail.com
}

Manuscript received: 10 October 2019. Revision accepted: 15 November 2019.

\begin{abstract}
Hichem K, Ramzi H, Djemoi M. 2019. Biodiversity and distribution of groundwater fauna in the Oum-El-Bouaghi region (Northeast of Algeria). Biodiversitas 20: 3553-3558. This study concerns the aquatic fauna of wells and springs in north of the city of Oum El Bouaghi, in the western part of the Tamlouka plain, north-eastern Algeria. 16 wells and two springs were selected and a seasonal sampling of the aquatic fauna was carried out from September 2017 to May 2018, covering periods of high and low water. Two types of traps were used: the phreatobiological net and baited traps. The composition of fauna was found to be 26 taxa and 6617 individuals, dominated by Crustaceans $47 \%$ followed by insects and shellfish $23 \%$ for each. Only one stygoby species was collected mainly: Pseudoniphargus djemoi.
\end{abstract}

Keywords: Amphipods, biodiversity, groundwater, Oum El Bouaghi, stygofauna

\section{INTRODUCTION}

Groundwater is hidden, discrete and poorly known. Groundwater is the largest freshwater reservoir in the world containing nearly $98 \%$ of the continental freshwater that can be directly mobilized (Gibert et al. 2002). Ecological research on subterranean aquatic fauna, and more particularly on groundwater aquifers accessible at wells, represents one of the aspects of applied phreatobiology that was developed since the improvement of appropriate methods (Cvetcov 1968; Boutin and Boulanouar 1983). The Mediterranean region is one of the hottest and most important points of aquatic fauna biodiversity in the Palearctic groundwater (Hadjab et al. 2018). Knowledge about their diversity in the North African part of the basin remains limited (Rewicz et al. 2014). The first stygobiological research started in Europe and multiplied rapidly (Botosaneanu 1986). Knowledge in this area was related to biogeographic point sampling (Pesce 1981; Malard 2003), or to the study of a specific biotope (Peck 1998), or to a systematic order study (Pesce 1981; Aït Boughrous 2007). Later, underground hydrobiology was undertaken in other continents, particularly in Africa, where only observations were published in the 1950s (Nourisson 1956). Stygobiological research is conducted in a major way in Morocco (Boutin and Boulaouar 1983; Messouli 1984 and Yacoubi-Khebiza 1990). This research has shown that the richness of the Stygobiont fauna is very variable from one region to another given the endemic nature of these species (Boutin et al. 1996), and could be a relatively effective tool for the detection of organic (Boulanouar 1995) and mineral pollution (El Gharmali 2005; El Adnani et al.2005). In Algeria, knowledge of the diversity of underground aquatic fauna is still incomplete, despite the relatively old data. Indeed, the underground fauna is known at the beginning of the century thanks to the descriptions of some species by Racovitza (1912). Actually, until today, ecological research on groundwater in Algeria was rare and partial. We can mention the work of Gurney (1908); Monod (1924); Gauthier (1928); Nourrisson (1956); Delamare Deboutteville (1960); Pesce and Tete (1978) and Pesce et al (1981). In northwestern Algeria, hydrobiology programs are developing at a growing rate in the Tafna watershed (Belaidi et al. 2004; Taleb et al. 2008; Mahi 2007; Belaidi et al. 2011 Benhadji 2013 and Mahi et al 2019). In recent years, underground fauna has been the subject of systematic studies to record the stygobian species of North-East Algeria (Merzoug et al. 2010; Piscart et al. 2013; Khaldoun et al. 2016; Hadjab et al. 2018 and Ayati et al. 2019), It is part of a global context of the stygobian fauna of Algeria and the stakes of the knowledge of the biodiversity of the underground ecosystems particularly the importance of invertebrates hosted by dug wells. So the objective of this study is to complete the results already obtained in the North-West / North-East of Algeria, by widening the study area. We try to expose the results of a stygobiological research in the region of Oum El Bouaghi and to assess the physicochemical quality of these wells and springs in order to highlight their sensitivity to the infiltration of pollutants.

\section{MATERIALS AND METHODS}

\section{Study area}

The sampling stations studied are all located in Mechta Lehteb north of the city of Oum El Bouaghi, in the western part of the Tamlouka plain. This plain is located between 
the Tellian Atlas in the north and the Sellaoua range in the south in the eastern extension of the Highlands. The Tamlouka plain is characterized by a semi-arid bioclimate, with hot summers and temperate winters. The geological study demonstrates that the Tamlouka plain is made up of a filling of foldo- quaternary river alluvium that rests on Upper Cretaceous formations (Vôute 1967). The Tamlouka groundwater table is contained in recent filling formations south of the Tellian Atlas. The flow of this groundwater is in the West-East direction. (Mebarki 2005).

\section{Stations studied}

A total of 16 wells and 2 springs were the subject of periodic study over a one-year period (2017 to 2018). They are aligned from east to west according to the direction of groundwater flow. These are wells that have been chosen from upstream to downstream (Figure 1). The piezometric level varies according to the sector where it is relatively low downstream and increases gradually as one moves upstream and hydraulically upstream of the water table (between 5 and 8 meters in upstream wells; 9 to 12 meter downstream). The choice was mainly made for old wells where the water is used for drinking or domestic use.

\section{Methods}

Different methods for sampling aquatic fauna from wells have been described by (Boutin and Boulanouar 1983). Well exploration was carried out by two methods: (i) With a phreatobiological net sampler (Cvetkov 1968; Bou 1974), $0.4 \mathrm{~m}$ diameter at the opening. Experience has shown that 10 net runs are sufficient to collect a representative well sample of fauna, with a filtered water volume of $1.025 \mathrm{~m}^{3}$ per meter of water height in the well, (ii) Using a baited trap developed by Boutin and Boulanouar (1983). The bait used is red meat, and the trapping time is between 16 and 24 hours. The trap must be placed at the bottom of the well, and must always be the same for a series of surveys. (iii) In the springs, only one technique was used: it consists of directly filtering the water through a $300 \mu \mathrm{m}$ mesh silk blasting net, stirring the sediment near the gryphon of the spring, upstream of the net (Messouli 1984).

The fauna collected, by each of the processes, is fixed on site with $96 \%$ pure ethanol. Invertebrates were identified according to the identification guides (Tachet et al. 1980; Pinkster 1993; Tachet et al. 2000) and counted in the laboratory. After washing with water, some of the collected sediments are stored in $96 \%$ pure ethanol.

\section{Statistical analysis}

Statistical analysis was accomplished with Xl STAT 2014, the analysis was chosen as the principal component analysis (PCA) is applied to the correlation matrix obtained from the 26 reduced centered variables measured at the 18 study sites. (Bautista 1997; Dagnelie 2011).

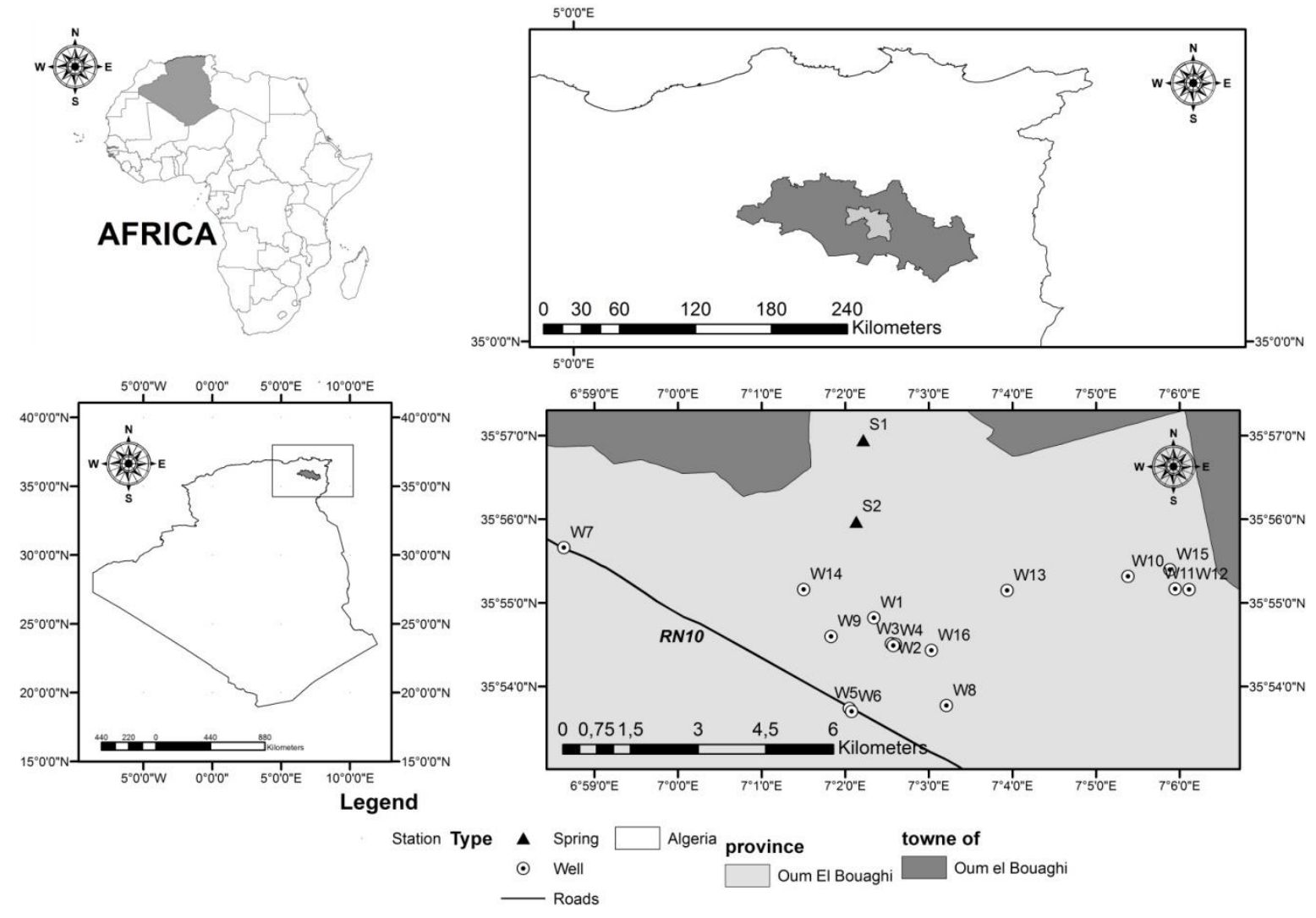

Figure 1. Map of geographical location of the study area, showing the sampling sites in Oum-El-Bouaghi region, Northeast of Algeria 


\section{RESULTS AND DISCUSSION}

\section{Global fauna composition}

The faunal analysis of the 18 stations led to the determination of 6617 individuals belonging to 26 taxa, and represented by four zoological groups: Crustaceans that are the most abundant (47\%), Insects (23\%), Molluscs (23\%), and Oligochets (7\%) (Figure 2). Among them, only one taxon has been identified as a stygoby species. It is an amphipod represented by Pseudoniphargus djemoi (Pseudoniphargidae).

\section{Taxonomic richness}

The analysis of Figure 3 on the spatial distribution of taxon richness shows a variation in taxon richness from one well to another. There were a total of 24 taxa, with the number of taxa varying from a minimum of 09 taxa collected in three wells W7, W14 and W16 to a maximum of 18 taxa collected in the well W3 and the two springs S1 and S2.

\section{Statistical analysis}

In the principal component analysis carried out on the faunal species collected and the sites (Figure 4), the F1-F2 plot is used because it provides a maximum of information (Fact. 1: $29.01 \%$ and Fact. 2: $21.67 \%$ ) on the existing correlations between the sites and their fauna characteristics. The circle of correlations allows the distinction of the following four groups of variables: (i) The group G1 correlated to the sites (W1, W2, W3, W4, W5, W6, W7, W8, W9, W13, W16, S1 and S2) is composed of the taxa: Viviparidae, Cyclopoidesind, Cypridopsisvidua, Chironomidae, Hydrophilidae, Heteroptera, Arrenuridae and Larvae undetermined. (ii) The G2 group correlated to sites (W10, W11, W12, W13, W14 and W15) is composed of species Dugesiasp, Lubriculidae, Turbificidae, Naididae, Pseudamnicola dupotetiana, Pseudoislamia sp., Daphniidae, Pseudoniphargus djemoi, Echinogammarus simoni,
Culicidae, Notonectidae and Baetidae. (iii) Groups G3 and G4 correlated with axes 1 and 2 in their negative ends are respectively composed of G3 (Oligochetes, Ilycipris, Ephemenoptera and Arrenuridae) and G4 (Lymnaeidae, Echinogammarus haraktis and Hydracarien) and statistically are not correlated with the sites.

\section{Discussion}

Most of the wells studied are located far from the city in fields or pasture areas. Also, the main causes of water pollution from these wells are most probably related to the discharge of raw wastewater that circulates in small canals very often used for irrigation, or more simply to discharge wastewater away from homes. In any case, this wastewater can infiltrate into the groundwater, generally not very deep and hence induces low oxygen levels, whose values vary between $(6.8 \mathrm{mg} / \mathrm{L}$ and $8.7 \mathrm{mg} / \mathrm{L})$.

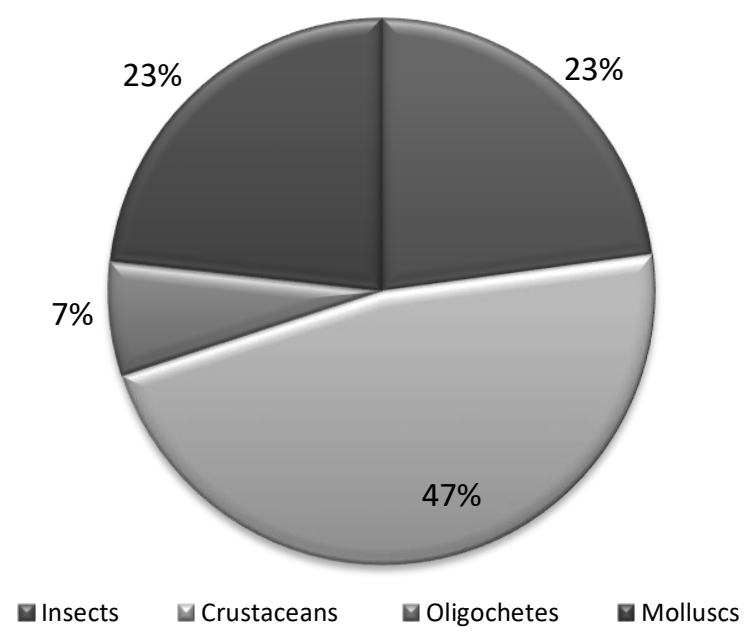

Figure 2. General structure of zoological groups

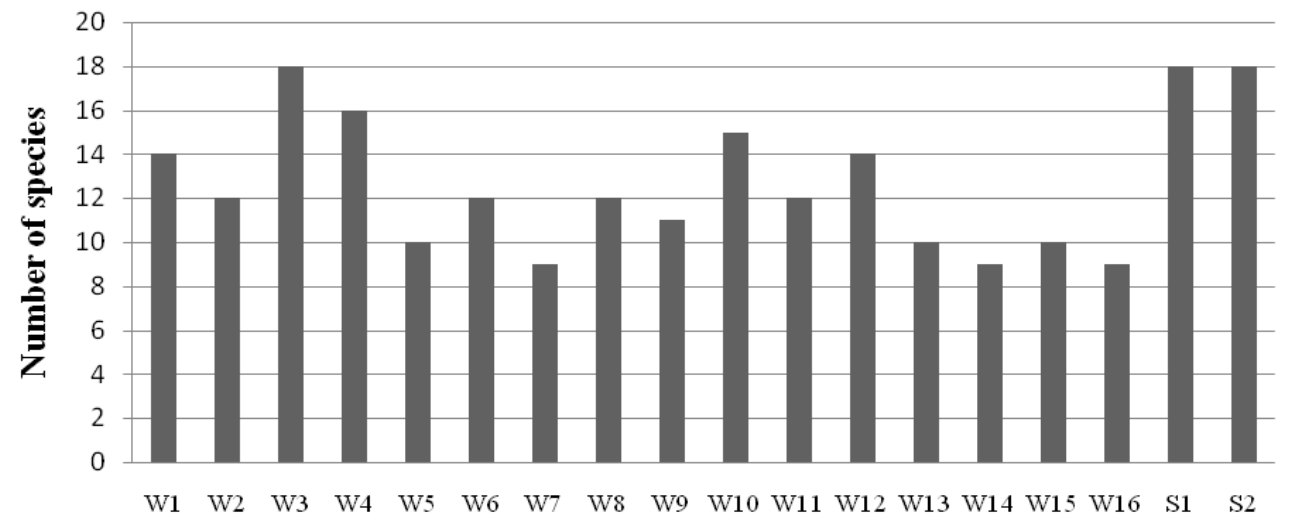

Stations

Figure 3. Spatial variation of the taxonomic richness of wildlife harvested in the different resorts 
Biplot (axes F1 et F2 : $50,68 \%$ )

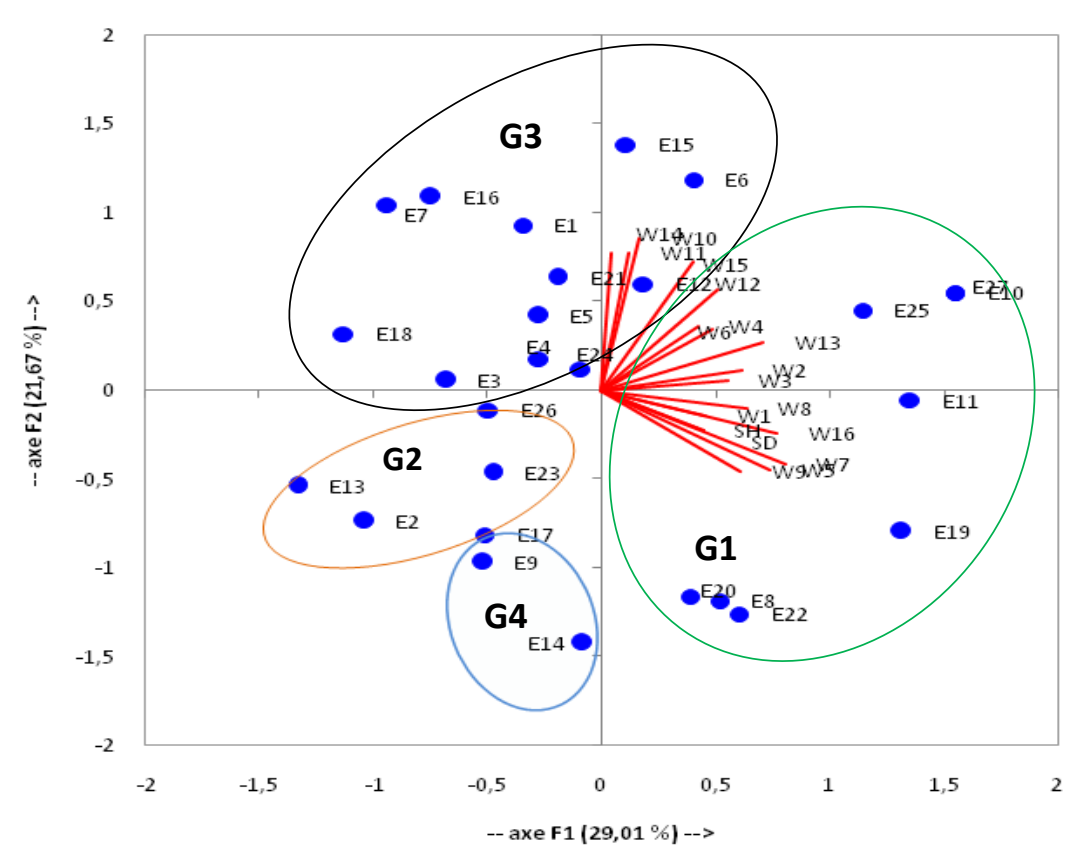

Figure 4. Circle of correlations of faunal diversity and their sites

The fauna harvested in all surveyed 16 wells and 2 springs consists of species of underground origin and largely of epigean species whose presence in the underground biotope may be accidental, due to rain, wind or floods that bring exogenous materials in the form of organic substances or living organisms to the underground environment. This presence may also be active and result from the voluntary movement of epigated animals to the underground environment (Creuzé des Chatelliers and Poinsart 1991). Indeed, the well has the character of an ecotone where the two forms of epigeous and hypogenous species coexist (Dalmas 1972; Ginet and Decou 1977).

The taxonomic richness observed in the wells of the study area is moderately high compared to other regions prospected in Algeria. Only 26 taxa and 6617 individuals are collected during this study. This richness remains lower than that recorded in the 12 wells dug in the alluvial groundwater of the Tafna (Belaidi et al. 2011) and in the 16 wells in the Oum-El-Bouaghi region, in north-eastern Algeria (Merzoug et al. 2010) and the 17 alluvial groundwater wells in the lower Tafna ( Haicha et al. 2012) , but it is higher than that of the 16 wells in the Mascara region (Lakhdari 2014), and that recorded in the 26 stations in the Oum-El-Bouaghi region ( Hadjab et al. 2018). This high number of taxa is probably the result of a higher sampling effor.

This is a mainly epigeated fauna, mostly made up of the group Crustacean, such as Amphipods Echinogammarus and Pseudoniphargus, Copepods Cyclopoidae and Ostracods. After the Crustacean, come to the Insects represented by the Diptera Culicidae, Chironomidae, and to a lesser extent the Ephemeroptera Baetidae. Finally, molluscs are very poorly represented by the gastropods Viviparidae. The presence of these species depends on the morphometry of the well, its layout and surface protection. Indeed, $70 \%$ of the studied wells are unprotected with an average water depth of $<8 \mathrm{~m}$. Crustaceans account for $47 \%$ of the fauna harvested. They are represented by 3 taxa: Amphipods are more abundant than Copepods and Ostracods. These crustaceans are believed to be of marine origin and to have colonized groundwater during tertiary marine regressions bypassing, either first through the coastal environment and then through fresh groundwater, or directly into coastal karst waters for large species. Their presence may be related to the texture of the aquifer system that characterizes the region. They are channels that can support these species at great depth (Boulal 2002).

Insects Diptera have a wide distribution in wells and a high capacity to colonize polluted and unpolluted biotopes and the lack of protection of the majority of wells inducing colonization by air, they are the most abundant group. They are invertebrates known for their tolerance to pollution and generally prefer high temperatures (Sabrina 2011). The dominant Culicidae family, with a relative abundance of $55 \%$, is the most common. It colonizes all wells during all sampling campaigns, a result in line with many kinds of research (Mahi 2007; Lakhdari 2014). In addition, some species of epigenetic pollution-resistant origin are present in the majority of surveyed wells, such as the insect larvae Chironomidae (Lakhdari 2014). 
According to the literature, Molluscs are never abundant in continental aquatic environments. The calcium content, the nature of the substrate are the predominant factors in the proliferation and distribution of shellfish in inland waters (Ghamizi 1998; Koramoko 2009). Only 16\% are represented in our harvests. These are the Viviparidae. Their rarity is said to be related to sampling methods (Haicha 2012).

The stygofauna of the studied tablecloth is represented by a Crustacean. This crustacean representation was observed in groundwater in all studied regions (Racovitza 1912; Monod. 1930; Nourisson. 1956 and Boulal. 2002). In our region, out of 37 stygoby species found in Algeria, only Pseudoniphargus (Pseudoniphargus djemoi) was captured in wells W1, W3, W4, W6, W8, W10, W11, W12, W13, $\mathrm{W} 14$ and W15. This number remains significantly higher than that recorded in the Tafna average (Belaidi et al. 2011) and in the Oum El Bouaghi region (Merzoug et al. 2010; Hadjab et al. 2018).

The scarcity of stygoby fauna in wells in the study area may indicate deterioration in well water quality given their role as a bioindicator species (Belaidi et al. 2004). In our case, the low species richness of stygofauna would be linked to groundwater contamination in most of the studied wells, except for wells W3, W8, and W13, by infiltration water, particularly agricultural fertilizers widely used in the region. Overall, there is heterogeneity in the distribution of aquatic fauna in the wells. Thus, the taxonomic richness varies from 09 to 18 taxa. This variation is linked to several factors, including the influence of the groundwater table, which largely determines the stability or otherwise of the groundwater habitat through hydraulic exchanges (Bruno et al. 2001).

According to (Sbordoni et al. 2000), differences between populations are more related to hydrological links than to geographical distance. Finally, the regular pumping of water from wells for mainly agricultural purposes generates an artificial modification of the piezometric level (Dole and Chessel 1986), causing the disappearance or migration of the fauna of the wells following destruction of the interstices.

Groundwater plays a major role in providing drinking water to the rural Algerian population and also contributes to the development of agricultural activities. The results obtained also show the importance of hydraulic exchanges between surface water and groundwater, particularly wells. This importance lies, among others, in the enrichment of the underground environment with organic matter that attracts stygofauna. Only one taxon has been identified as a stygoby species. It is a crustacean Amphipod Pseudoniphargus djemoi that is first mentioned in the groundwater of the Oum El Bouaghi region (Dole-oliver et al. 2018). The results obtained in this work highlight the need to increase the number of surveys and spatial extent, given the spatial and temporal heterogeneity of the faunal composition. To better understand the qualitative study of groundwater quality and to determine its influence on the stygofauna, a greater sampling effort undertaken in this set will provide an important step in establishing the role of these variables in determining the diversity and structure of groundwater fauna and the absence of hypogonadal species.

\section{ACKNOWLEDGEMENTS}

We thank Dr. M. Rached Kanouni for the statistics analysis contribution, Dr. A.C. Rebbah for the Map conception, finally Prof. N. Ghorraf for language revision.

\section{REFERENCES}

Aït boughrous A. 2007. Biodiversité, écologie et qualité des eaux souterraines de deux régions arides du Maroc: le Tafilalet et la région de Marrakech. Thèse. Doc. Fac. Sc. Univ. Marrakech, Morocco. [French]

Ayati K, Hadjab R, Khammar H, Sonia D, Christophe P, Ezzeddine M. 2019. Origin, diversity and distribution of freshwater epigean amphipods in Maghreb. Annales de Limnologie-Intl J Limnol 55 (13): $1-9$.

Bautista M.G, Smith D.W, Steiner R.L A. 1997. Cluster-based approach to means separation. J Agric Biol Environ Stat 2 (2): 198-211.

Belaidi N, Taleb A, Gagneur J. 2004. Composition and dynamics of hyporheic and surface fauna in a semi-arid stream in relation to the management of a polluted reservoir. Annales de Limnologie-Intl J Limnol 40 (3): 237-248

Belaidi N, Taleb A, Mahi A. et Messana G. 2011. Composition and distribution of stygobionts in the Tafna alluvial aquifer north-western Algeria. Subterranean Biol 8: 21-32.

Benhadji N. 2013.Contribution à l'étude de la faune hyporhéique des zones de sources dans les Monts de Tlemcen. [Thèse. Magistère]. Univ. Tlemcen, Algéria. [French]

Botosaneanu L. 1986. Stygofauna mundi.A Faunistic, Distributional and Ecological Synthesis of the World Fauna inhabiting subterranean Waters including the Marine Interstitial. E.J. Brill Publ., Leiden.

Boulal M. 2002. Recherches phréatobiologiques dans le Souss et les régions voisines du Maroc occidental: Qualité de l'eau, Biodiversité, Écologie et Biogéographie Historique des espèces stygobies. [Thèse de doctorat d'État], Fac. Sci., Université Cadi Ayyad, Morocco. [French]

Boulanouar M. 1995.Faune aquatique des puits et qualité de l'eau dans les régions de Marrakech et des Jbilet. Statut et dynamique d'une population de Proasellus coxalis africanus Crustacés Isopodes Asellidae des Jbilet. [Thèse de doctorat d'État], Fac. Sci., Université Cadi Ayyad, Semlalia, Marrakech, Morocco.

Boutin C, Boulanouar M, Yacoubi-Khebiza M. 1996. Un test biologique simple pour apprécier la toxicité de l'eau et des sédiments d'un puits. Toxicité comparée, in vitro, de quelques métaux lourds et de l'ammonium, vis à vis de trois genres de crustacés de la zoocénose des puits. Hydroécologie Appliquée 7 (1-2): 91-109. [French]

Boutin C, Boulanouar M. 1983. Méthode de capture de la faune stygobie: Expérimentation de différents types de pièges appâtés dans les puits de Marrakech. Bulletin Faculté des Sciences Marrakech Section Sciences de Vie 2: 5-21. [French]

Bruno MC. Loftus WF, Perry SA. 2001. Preliminary data on microcrutacean communites from ground waters in the southern Everglades. Eve L. Kuniansky, 89-97.

Creuzé Des Châtelliers M, Poinsart D. 1991. Caractéristiques des aquifères alluviaux et densité faunistique du sous écoulement du Rhône. Hydrogéologie 3: 201-215. [French]

Cvetkov L. 1968. Un filet phréatobiologique. Bull Inst Zool Mus Sofia 27: 215-219. [French]

Dagnelie P. 2011. Statistique théorique et appliquée. De Boeck, Bruxelles. [French]

Dali N. 2009. Resources and integrated water management of the Gareat el Tarf basin (wilaya de Khenchela). [Mémoire de Magister]. Univ Annaba, Algeria. [French]

Dalmas A, 1972. Contribution à l'étude des caractères physicochimiques et de la faune de quelques puits artificiels de la Provence. [Thèse doctorat 3è Cycle], Université de Provence, French. [French] 
Delamare Debouteville C. 1960. Biologie des eaux souterraines littorales et continentales. Hermann Ed. Paris, French. [French]

Dole M. J, Chessel D. 1986. Stabilité physique et biologique des milieux interstitiels. Cas de deux stations du Haut-Rhône. Annales de Limnologie-Intl J Limnol 22 (1): 69-81. [French]

Dole-Olivier M. J, Hafid H, Piscart C. 2018. A new groundwater species of Pseudoniphargus Amphipoda: Pseudoniphargidae from Algeria. Zootaxa 4482 (1): 125-139.

El adnani M, Aït Boughrous A, Nejmeddine A, YacoubI-Khebiza M. 2005. Impact d'une activité minière sur la biodiversité et la qualité des eaux souterraines près de Marrakech Maroc. Comm. Conférence Internationale "Biodiversité: Sciences et Gouvernance", UNESCO, Paris, 24-28 Janvier 2005. [French]

El Gharmali A. 2005. Impact des résidus miniers et des eaux résiduaires sur la contamination métallique des écosystèmes aquatiques et terrestres de la région de Marrakech, Marocco. [Doctoral dissertation]. Fac. Sci., Université Cadi Ayyad, Semlalia, Marrakech, Morocco. [French]

Gauthier H. 1928. Recherches sur la faune des eaux continentales de l'Algérie et de la Tunisie. Impr. Minerva. Alger, 419p, Pl. I-III. Carte 6 H. t., Algeria. [French]

Ghamizi M. 1998. Les Mollusques des eaux continentales du Maroc: Systématique et Bioécologie. Doctorate Diss, Marrakech, [Morocco]

Gibert J, Daharveng L. 2002. Subterranean ecosystems: a truncated functional biodiversity. Bioscience 52: 473-481.

Ginet R, Decou V. 1977. Initiation à la biologie et à l'écologie souterraines. J.P. Delarge, Paris. [French]

Gurney R. 1908. A new species of Cirolana from a fresh-water spring in the Algerian Sahara. Gustav Fischer Verlag, Germany.

Hadjab R, Khammar H, Nouidjemn Y, Saheb M, Merzoug D. 2018 Ecology and biodiversity of underground water in a semi-arid region of the Hauts Plateaux of Eastern Algeria. World J Environ Biosci 7 (2): $39-44$.

Haicha. 2012. Contribution à la connaissance de la stygofaune d'Algérie. Etude de la faune des puits de la nappe alluviale de la basse Tafna [Thèse. Magistèr]. Univ. Tlemcen, Algeria. [French]

Karamoko M. 2009. Étude de la biologie, de l'écologie et du comportement d'un escargot terrestre d'intérêt économique, Limicolaria flammea Müller, 1774, en milieu d'élevage. [Thèse de doctorat unique]. Université de Cocody-Abidjan, Ivory Coast. [French]

Khaldoun L, Merzoug D, Boutin C. 2016. Faune aquatique et qualité de l'eau des puits et sources de la région de Khenchela Aurès, Algérie nord-orientale. Bull Soc Zool Fr 138 (1-4): 273-292. [French]

Lakhdari FT. 2014.Contribution à la connaissance de la stygofaune d'Algérie: Etude de la qualité de l'eau et la faune aquatique des puits de la region de Mascara Nord-Ouest Algérien. Thèse de Magistère en Ecologie et Biodiversité des Ecosystèmes Continentaux. Option: Ecosystème Aquatique. Université Abu Bakr Belkaïd, Tlemcen, Algéria. [French]

Mahi A, Di Lorenzo T, Haicha B, Belaidi N, Taleb A. 2019. Environmental factors determining regional biodiversity patterns of groundwater fauna in semi-arid aquifers of northwest Algeria. Limnology 20: 309-320.

Mahi. 2007. Contribution à l'étude de la faune stygobie de la région de Tlemcen Nord-Ouest Algérien. [Thèse. Magistère]. Univ. Tlemcen, Algéria. [French]

Malard F, Ferreira D, Dolédecs et Ward JV. 2003. Influence of groundwater upwelling on the distribution of the hyporheos in a headwater river flood plain. Archiv. Für Hydrobiologie 157 (1): 89116.
Mebarki A. 2005. Hydrologie des bassins de 1'Est algérien: ressources en eau, aménagement et environnement. [Thèse d'Etat]. Université Mentouri de Constantine, Algéria. [French]

Merzoug D, Khiari A, Aït boughrous A, Boutin C. 2010. Faune aquatique et qualité de l'eau dans les puits et sources de la région d'Oum-elBouaghi Nord-est algérien. Hydroécologie Appliquée 17: 1-22. [French]

Messouli M. 1984. Les Crustacés Amphipodes souterrains du Groupe Metacrangonyx: Répartition, systématique et phylogénie. Thèse 3éme cycle, Fac. Sci., Université Cadi Ayyad, Semlalia, Marrakech, Morocco. [French]

Monod T. 1924. Sur quelques Asellides nouveaux des eaux douces de l'Afrique du Nord. Bull Soc Hist nat Afrique du Nord 15: 327-336. [French]

Monod, T. 1930. Contribution à l'étude des" Cirolanidœ". Masson et cie. [French]

Nourrisson, M. 1956. Etude morphologique comparative et critique des Typhlocirolana Crustacés isopodes Cirolanides du Maroc et de l'Algérie. Bull Soc Sci Nat Phys Maroc 36: 103-124. [French]

Pesce GL, Tete P, De simone M. 1981. Ricerche faunistiche in acque sotterranee freatiche del Maghreb Tunisia, Algeria, Morocco et dell'Egitto. Natur Soc Ital Sc Nat Museo civ Stor Nat E Acquario civ Milano 72 (1-2): 63-98. [French]

Pesce GL, Tete P. 1978. Microparasellides d'Algérie Crustacea: Isopoda. Rev Zool Afr 92 (4): 992-1001.

Pinkster S. 1993. A revision of the genus Echinogammarus Stebbing, 1899, with some notes on related genera Crustacea, Amphipoda. Mem Mus Civ Storia Nat Verona [Italien]

Piscart C, Merzoug D, Hafid H. 2013.A new species of Echinogammarus from Algerian freshwaters, Echinogammarus haraktis n. sp. Peracarida, Amphipoda. Crustaceana 86 (13-14): 1623-1633.

Racovitza EG. 1912.Cirolanides première série. Archives de Zoologie Expérimentale et Générale, 5e Série, 10: 203-329. [French]

Rewicz T, Grabowski M, MacNeil C, Bacela-Spychalska K. 2014. The profile of a perfect' invader the case of killer shrimp, Dikerogammarus villosus. Aquatic Invasions 93.

Sabrina H. 2011. Recherches sur la faunistique et l'écologie des macroinvertébrés des cours d'eau de Kabylie.Universite de Tizi Ouzou, Algeria. [French]

Sbordoni V, Allegrucci G, Cesaroni D. 2000. Population genetic structure, speciation and evolutionary rates in cave dwelling organisms. Semlalia, Marrakech, Morocco.

Tachet H, Bournaud M, Richoux P. 1980. Introduction à l'étude des macroinvertébrés des eaux douces. CRDP. [French]

Tachet M, Bournaud M, Richoux P, Usseglio-Polatera PH. 2000. Invertébrés des eaux douces: Systématique, Ecologie, Biologie. Ed CNRS-Paris. [French]

Taleb A, belaidi N J, Sanchez Perez M, Vervier P, Sauvage S, Gagneur J. 2008. The role of the hyporheic zone in the nitrogen dynamics within a semi-arid gravel bed stream located downstream of a heavily polluted reservoir Tafna wadi, Algeria. River Research and Applications 24: 183-196.

Vôute C.1967. Essai de synthèse de l'histoire géologique des environs d'Ain Fakroun, Ain Babouche et les régions limitrophes. Publication du service de cartes géologiques. NS Bull (36): 3. [French]

Yacoubi-Khebiza M. 1990. Écologie, Biogéographie des biocénoses aquatiques des nappes alluviales de quelques vallées du Haut-Atlas de Marrakech Maroc. Paléogéographie des crustacés phréatiques. Thèse doctorat 3éme cycle. Fac. Sci., Université Cadi Ayyad, Semlalia Marrakech, Morocco. [French]

Younssi HE. 2009. Depletion of the water table in the F'kirina region (wilaya d'Oum El Bouaghi), and its impact on water resource management. [Mémoire de Magister]. Univ Annaba, Algeria 